\title{
合成ゴム ハイカーO.R.の性狀操作及び配合に就て
}

\author{
Rubber Age (N. Y.), 1941, 48, 315-8
}

营田居美锌

\section{一般性狀及び用途}

ハイカーO.R.は一合成ゴムであつてブタデェンより製造せられるものである。外数及び物理的性質は栽

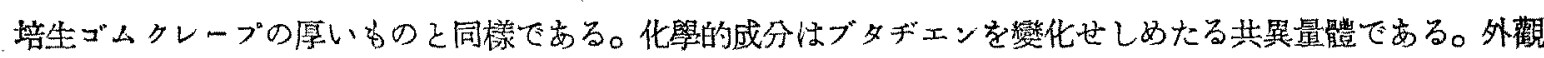

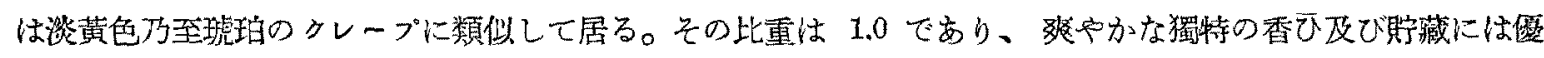

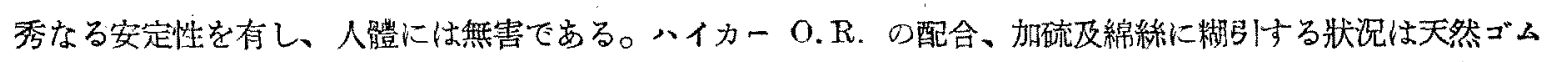
と同樣でする。ロール操作は天然ゴムと非常によく類似して居るが、ミルロールは比較的冷却 (120F)にして 牤かねばなら欢。而してロールの摩擦比を低くするか(1:1.3:或ひはなくしておかねばならね。

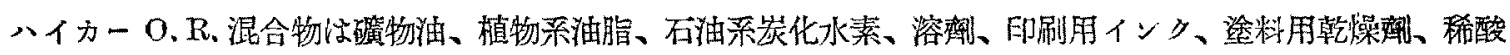

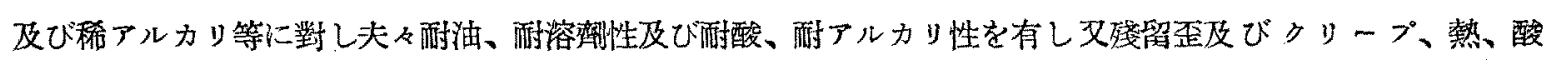
化、疫等、老化及び磨隇等の抵抗性は良好であると報告されて居る。是等の諸性質の1つ或ひは夫以上を必慗 とするものにハイカーを利用するのである。

\section{ハイカーの配合物}

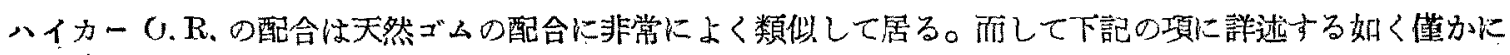
特別の柏逵があるのみにて天然ゴムと大體同樣の原理を應用する事が出來る。

\section{硫黄及促進别}

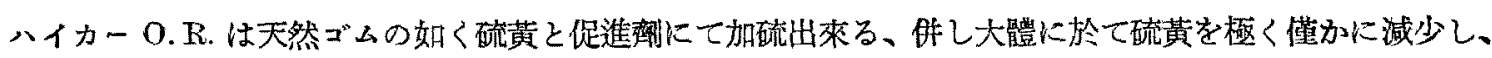

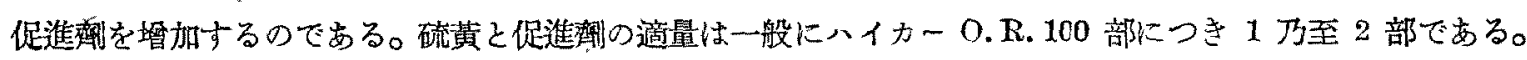
トレッド配合に於ては硫黃 1.25 部、ベンゾチアヂル・ヂサルファド 1.25 部は硫黄及び促潐劑の適當なる比率

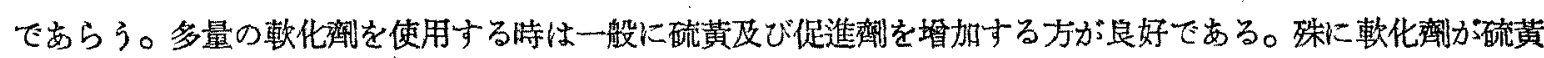

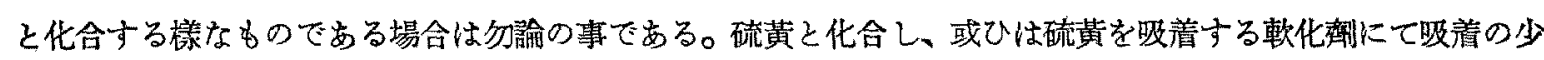
ない順に列擧するならばカードライト、ロヂン、クマロン、及びュールタールの順である。

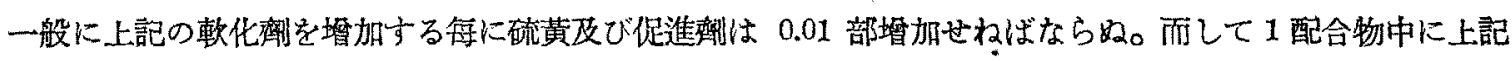
㜞化劑が 15 部配合されて居る場合はハイカー O.R. 100 部に對し硫黄 1.25 部促進劑 1.25 部を配合せね ばなら20若しその配合物が高洫用に使用されるものであるならば過剩の硫黄は使用中にその伸張高を減少し

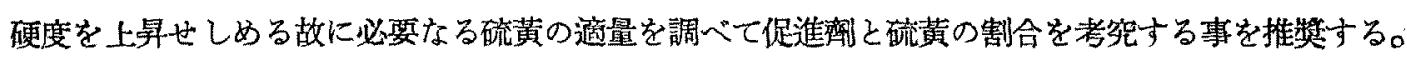

ヘイカー O.R. 加硫系數に就ての異棰促進劑の影響は大體天然ゴムと同樣である。

而して更に多量の促進劑を使用するか或ひはテトラォチル・チウラム・ヂサルフ、イドの如き超促進洲を使

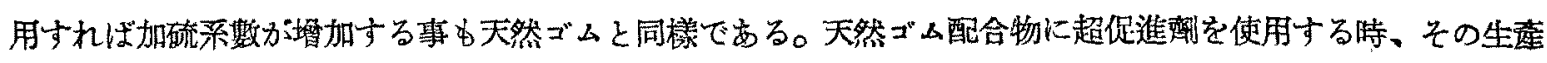

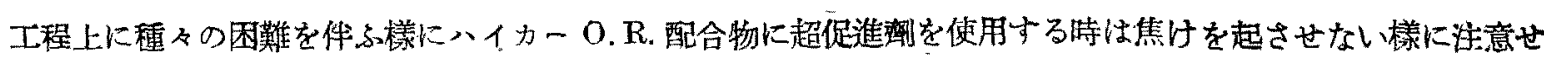
ねばならぬ 


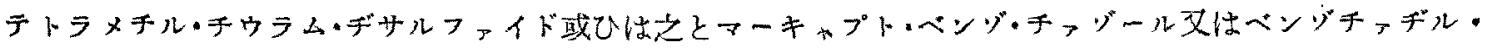
ヂサルファイドとを作用して遊離硫黄をなき樣にするか或ひは最少限量の硫黄を使用すれば最良の䩂熱性配合 物が得られる。

金屬酸化物に言及するならばリサージは加硫には大變满足すべき促進劑である。りサージ配合に於ては八 イカー0.R.100部りサージ7万至10 部硫黄 1 万至 2 部の割合に使用すれば良い。

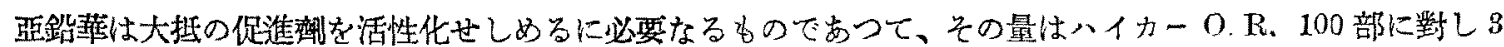
乃至 5 部を使用する事を獎める。

\section{敞 ，料}

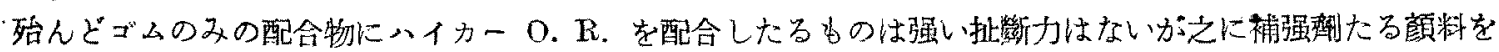
添加すれば强い扯断力を有する配合物が容易心得られる。チャンネルブラックは此の點に於て最も良好なるむ

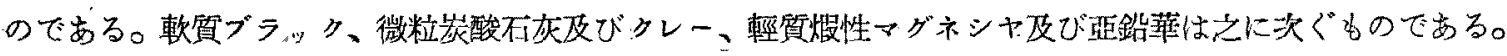

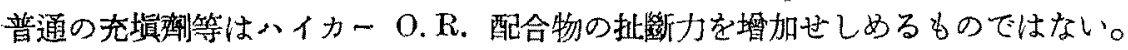

チャンネルブラ。タは從來强扯斷力、可偠及磨减に良結果を與へるものとして伐用されてるる。

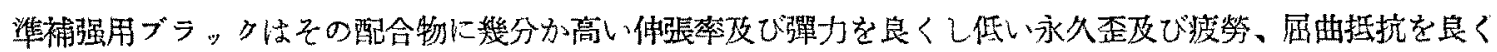
するものであるが批斷力はテャンネルブラックより劣る。

・前述せる如く亞鉛華は促進劑の活性劑として少量使用されてるる。ハイカー 0. R.100 部に對し 25 部万至 150 部の亞鉛華を配合せしものは增補用及び建筑用として良好なるものである。

或る微粒質クレーは或る程度の扯断力を與へ而して淡色物に使用出來る。併しながら之等配合物の永久歪は 高く反撥彈力性は弱しバライト、ホワイチ。グ、リトホンの如き充埧臍は第一に原價を下げるために使用せら れるものである。ホワイチ:グは操作及びその配合物の押出し作業を容易ならしめる。この樣な充買衤を使用 する時はその抗張力、殘留歪及び磨减抵抗等の物理的性貿を鈛牲にせねばならぬ。

熖類は拥出し作業を容易ならしめ、日光及び屈曲に依る龜裂を防ぐために使用せられる。

之等臘類はハイカー O.R 100 部に對し2 部以上使用してはならない。何故ならば多量の臘を使用する時 は配合物の締りを因難ならしめ、而子多量のブルーミングを生ざしめ、その物質の粘着性を減少せしめるもの である。・イカーO.R.の配合物に最为適當した普通の臘類はパラフィン、シンセラ、サンプルーフ及びーリ オジンである。

\section{軟 化}

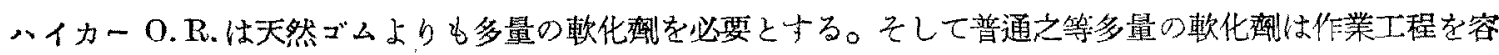

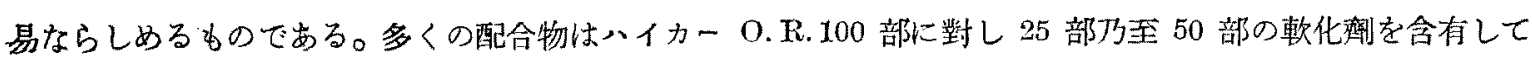

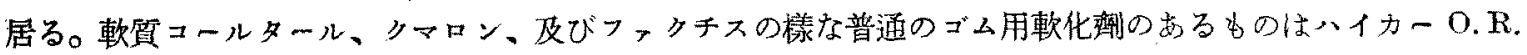

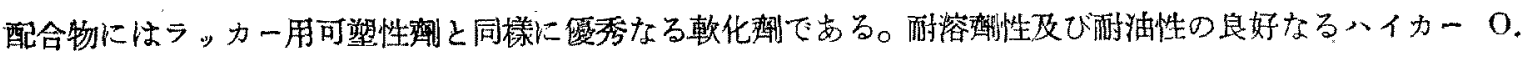

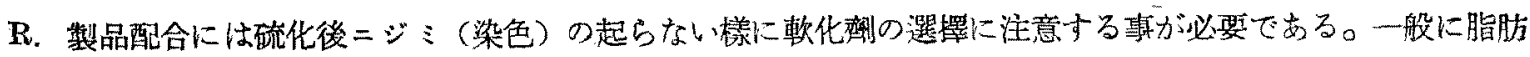
族或ひはパラフ、シ樣の物質を多量に使用すればする程軟化劑としての效力はなくなる。

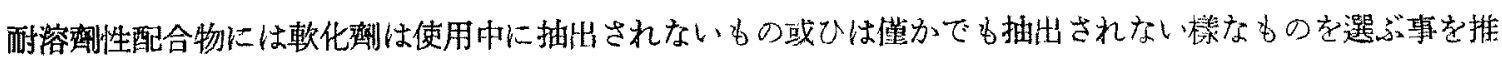
獎する。斯樣にすれば出來た製品は長期の使用に耐入得るめのが得られるのである。後述する如く大抵此の種

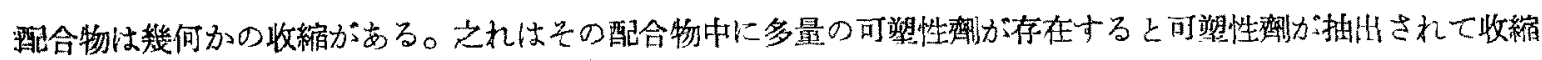




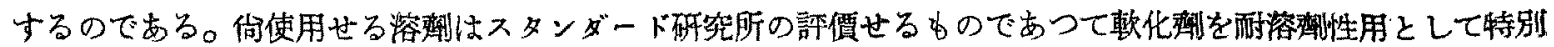
に選擇して居ない。

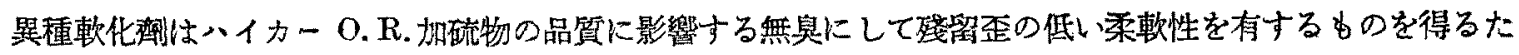

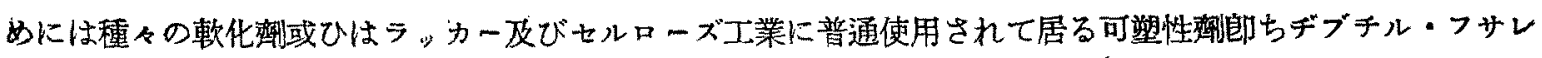

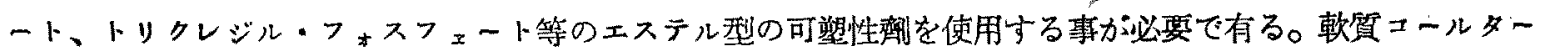

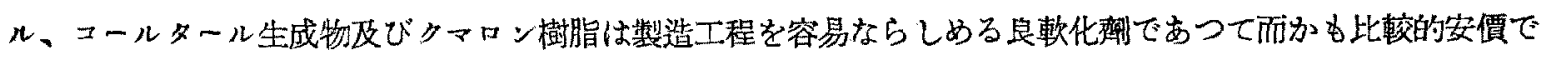

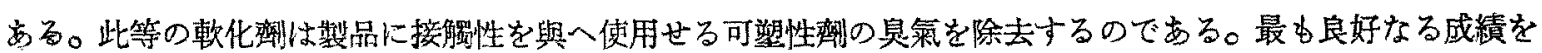

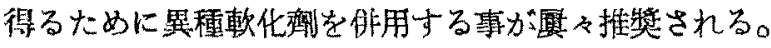

製品の反撥力登增加寸るためにヂブチル・フサレート、トリリレヂルフォスフェート及びバードールB及び トリアセチンの如き軟化劑を使用する。更に粘き製品或ひは溶液に粘着性を與へる配合物を得るために軟質 コ ールタール、ヂオクチル・フォレート、ネボール、クマロン樹脂及び分散油 10 號等の軟化卿が使用される。 押出し作業を容易ならしめるために、テトラリン、軟質フォクチス、ウールグリース(デグラ)、スデアリン

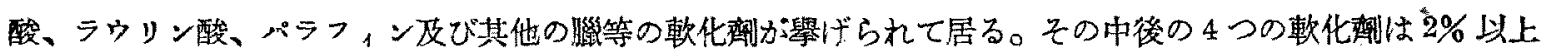
使用してはならない。

老化防止涭

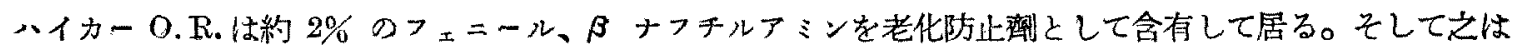
邀當なる老化防止となる。耐熱性䌘品を必要とする時はハイカーO.R.100部に對し1 万至 5 部のエーヂラ イトレデン“D”アミノックス、B.L.E. 或ひはフレクトル“B” 又は“H”の如きヶトンアミン反應生成物 来の老化防止劑を港加する事が推獎されてるる。

\section{天然コム及び其他合成コムとの配合}

ハイカー， R，は天然ゴム或ひは再生ゴム何れにも、如何なる割合にても混合する。そうしてこの謂合は

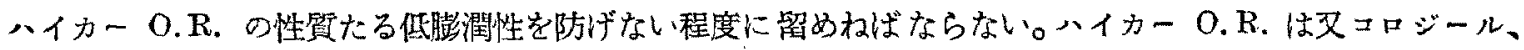
ネオブレン、支びチオコール等と混合する、而してその樣な混合物は各々一つ宛の性留よりる組合せたる性質

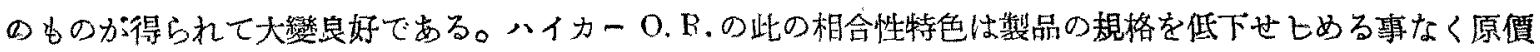
を引下げる事が出來て配合者に都合が好い。

、イカー O.R.を天然ゴム、コロジール、ネオブレン及びチオコール等と混合せしめる時は混合する前に混

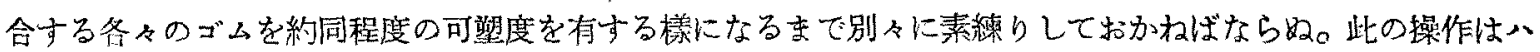
イカーO.R.に或る㜞化劑を混合する時にも施す必要がある。郎ち配合する物質を混合する前に同程度の柔軟 度性にして置くのである。

\section{八イカーの操作}

ハイカー0、R．の操作に就て仔細に檢討するならば天然ゴムの操作法とは工場及研究公操作共に異なつて居

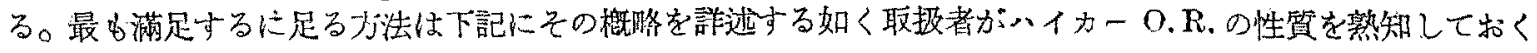

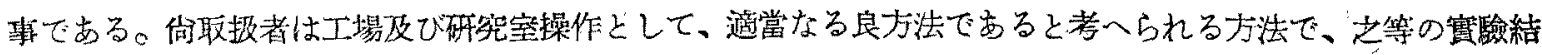

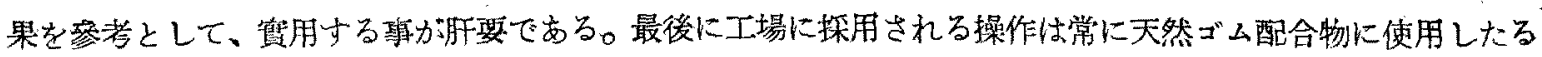
法と䬳り相䎭して屆ない。

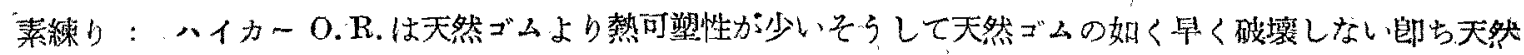


ゴムと同程度には破壊しない、以上の理由にて、イカーO.R.は素練り作鄴中ロールに熱を持つのでロールを 比較的冷却しておかかなければならぬ、同時にロールの包轉比を出來るだけ落して摩擦による熱の上开を防がれ ばならぬっロールの包轉比を 1〜1.3 となし、ロールの溫度を $120^{\circ} \mathrm{F}$ 上下に保つ事が最为满足な榜である。 、イカー O.R.は天然ゴムと同程度まで破壤しないので製造工程を圆滑ならしめる篇にその配合量は素練り 或ひは破壊作業と重要なる關係を有す。此の理由で天然ゴムと比較してなるべく配合量を小さくすればよい。

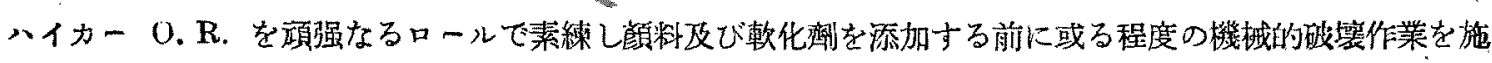

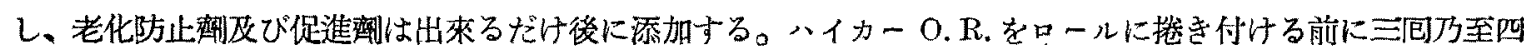
包口ールを通蓑を推獎する。適當なる素練り時間は口ールの大きさ又はハイカー．R．の量に基因する が 5〜15 分である。

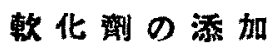

ハイカーO. R. 100 部㜞下劑 30 部以下の封には次の加き方法を推獎する。

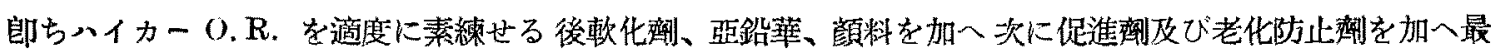
挠に硫黄を添加する。

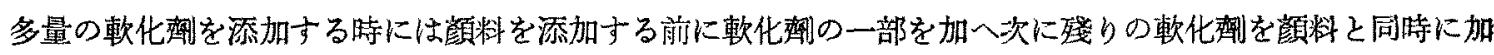
へる但し着色料がテャンネルブラックの時には叉別である。若し多量のチャンネルブラっクを配合する時には

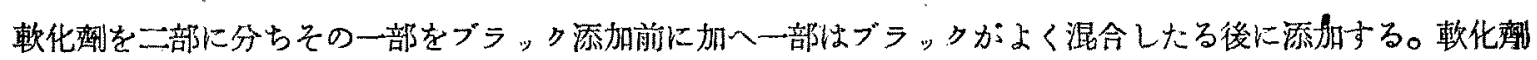

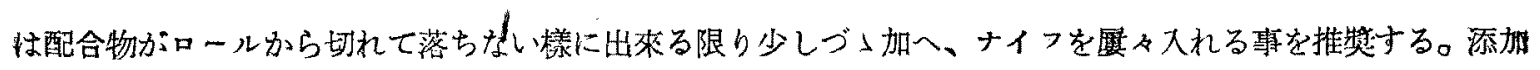
に要する時間は使用乾化剽の性質に传つて異なる。コールタール、タマロン及びその類似物はヂブチール・フ サレート、トリクレデール憐酸辟第の如きェステル型の可塑性劑より早く混合する。

\section{料䫝 加}

チャンネルブラッタが多量にして軟化懠が少量なる特別配合物は配合する時に能く注意しその粘り量を少く する事が緊要で有る。ブラックはウールグリース、パラフィン、スデアリン酸等のダリース樣物犋を添加する 前に徐々に加二ロールに港きついて居るゴムがョールより落ちない樣にせねばならない。時ふナイフを大れて 混合する事は混合を容易ならしめるもので有るがロール上にブラッタや顏料が末だ混合せざる時はナイフを入 れてはならない。チャンネルブラックの上く分散したる配合物の邪断面は黑光りを呈して居る。若し配合した ものが其の樣な外觀を是してるない時は之れを一度冷却ぜしめ然る後再びロールにかける樣にせねばならな W.

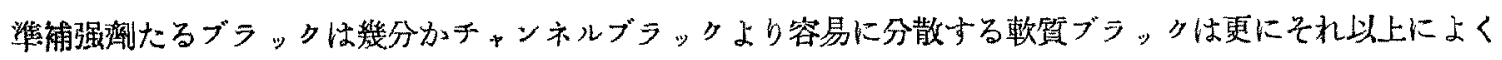
分散する。睢々同じ方法にて混合するに僌質ブラッタは混合か稍々短時間です然も配合に左程注意を要しな い場合を除いては軟筫ブラッタはチャンネルブラック配合物に次ぐものであるが、一配合中に硬質及び軟質ブ ラックを配合して居る時は例へ雨者を同特に添加して滿足な配合物が得られ樣とも先に硬質ブラックを加へる 事が最も是好である。

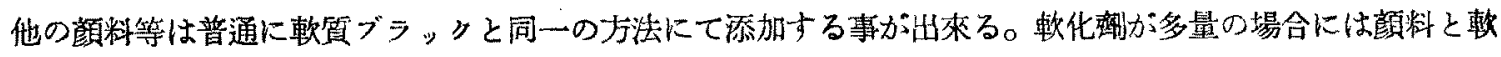
化第とを交互に加へる、そうして何れす決して愛速に加へてはならない。

\section{カレンダー㙫作}

、イカー O.R.配合物は一般的にカレンダー操作は非常によい。叨論特別にカレンダーの最邀調子を各別偑 


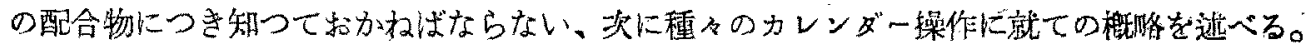

薄物配合物： ハイカーO.R.配合物は同じ可塑度を有するゴム配合物より粘着性が少ない。そしで或る㙃 合には重ね貼り部の密请をよくするために下部のスクれズカレンダーを使用する事が必妿である。

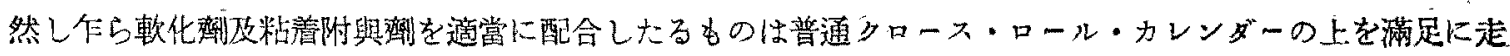
る。

カレンダーにては八イカーU.R.配合物は氣泡が入り易い倾向がある故に天然ゴム配合物より幾分か氣泡が 多い。例し乍らライナーに固く捲きつける时は大抵の場合之等の氣泡を除去し、天然ゴム配合物の如く殆んど 均一な厚さのシートになす事が出來る。

天然ゴムとは異なりカレンダー溫度が高くても粘着性及び重ね岾り部の密着を篔加するものではない。大抵

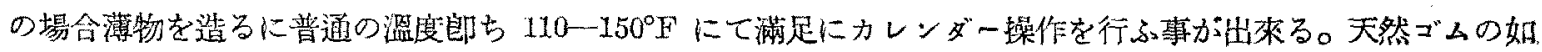
くカレンダーの厄轉㘿は备々配合物に低つて加減せねばならない。

フリタション操法：フリクション操作を施す配合物はその作業が十分よく行なひ得る樣な配合にせねばな

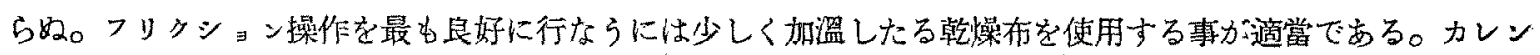

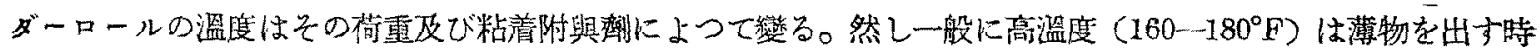
よりもフリクション作業に必要である。

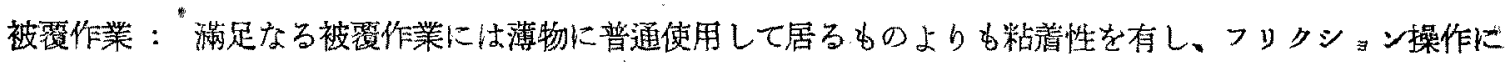
使用して居るものより稍々粘湴性の少ない配合物が適當である。

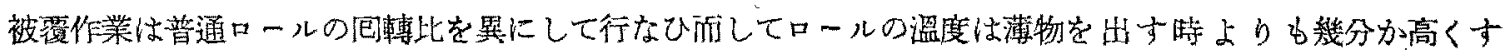
る。

满 板 制造

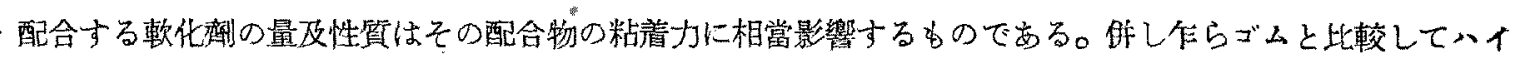
カーO R.の特性たる粘着性の相違にもよるが一般に如何なる種類の配合に於ても㙋合せ作業には溶劑又は粘 着附與劑を使用する事が必要である。メチルエチルケトン或ひはメチルエチルケトンにエチルフサリル・エチ

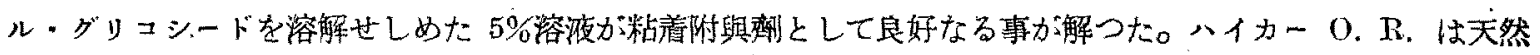
ブムの如く容易にガス類を透過せしめない故に貼合せ中に合せ目に空氣が殘つて居ない、樣にする事が朋要であ る。

\section{中 整造}

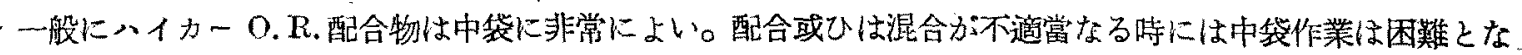
る。非常に好調子に中袋作業を行はんとするには押出し機體及で螺子を冷却しておく索である。而して非常に 弱い㴘度を與へると押出されて來たもの」表面が本滑となる。

\section{成型及び加硫}

ハイカーO.R.配合物の成型攻び加硫は天然ゴムと同樣の翼際蜼操作及び天然ゴムに使用したる設借にて出 來る。

\section{ハイカー．R. 配合物の金濁類に對する接着}

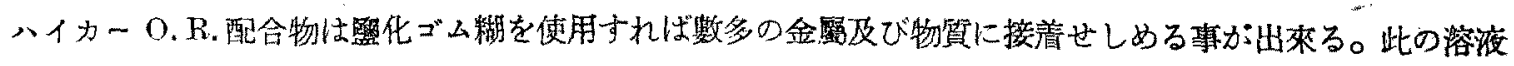
はトルオール 100 部に蜸化ゴム 15 部を溶解せしめたるものとテトラリン、デブチルフサレート、或ひはト 
リフェニール・フォスフェートの如き可望性劑の】部を混和せしめたるものである。接着せしめる物體の表面 は美しく洗ひ、油及びグリース在除去する。大抵の場合は表面を厗熊せしめるか或ひはザラザラにしておく。

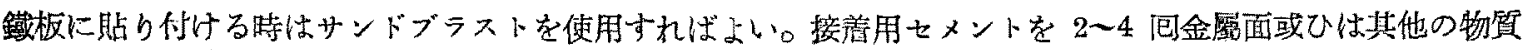

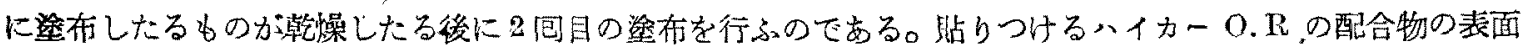

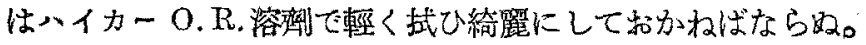

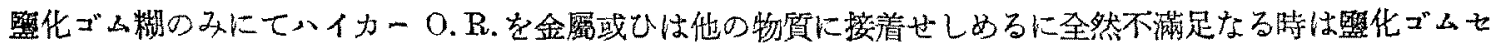
メント及びハイカーＯ．R.配合物糊を使用する事を推獎する。

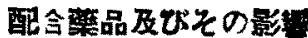

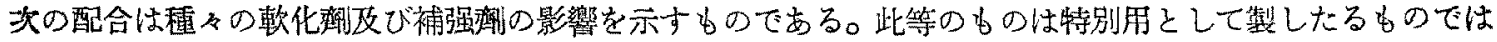
ないがー般軟化酒の種類の量を增加し、普通ガフブラック３種を多量に使用したる處明が々の物理的性質に 相兞ある事を示して居る。

\section{㜞化嘅の研究}

次に揭ぐる配合は軟質コールタール型の軟化劑の增量に就ての影響を示すものである。軟化劑を相當に增量

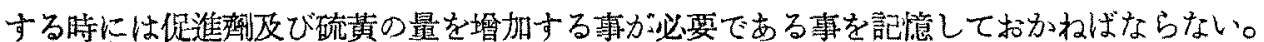

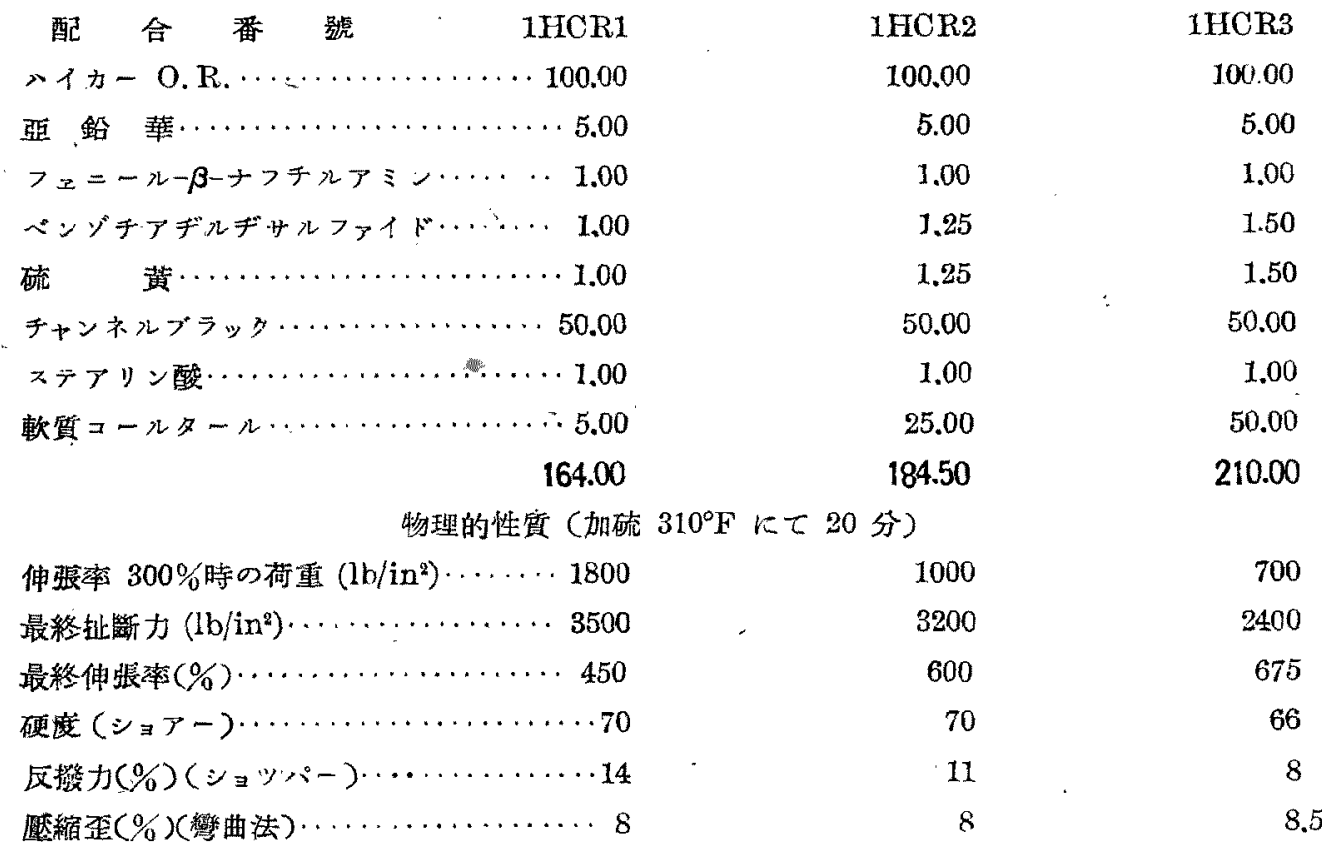

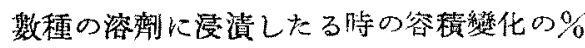
○クザン
48 時間 $25^{\circ} \mathrm{C} \cdots+3$
サーコライト油 48 時閒 $100^{\circ} \mathrm{C} \cdots+6.1$
0

(Circo light proc oil)

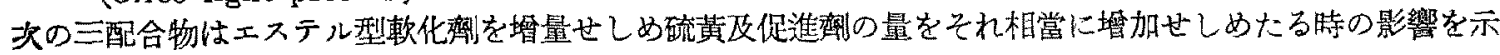
するのである。

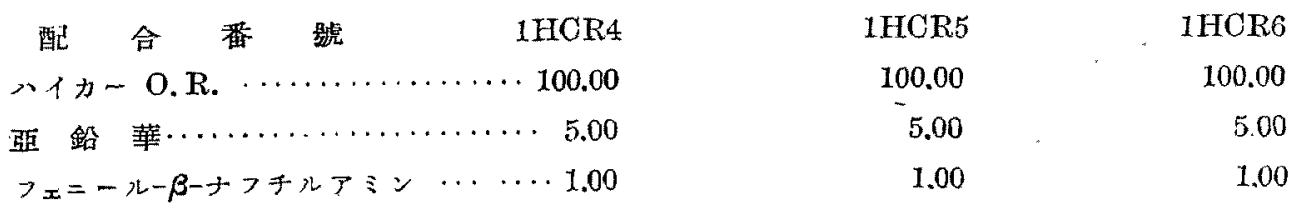




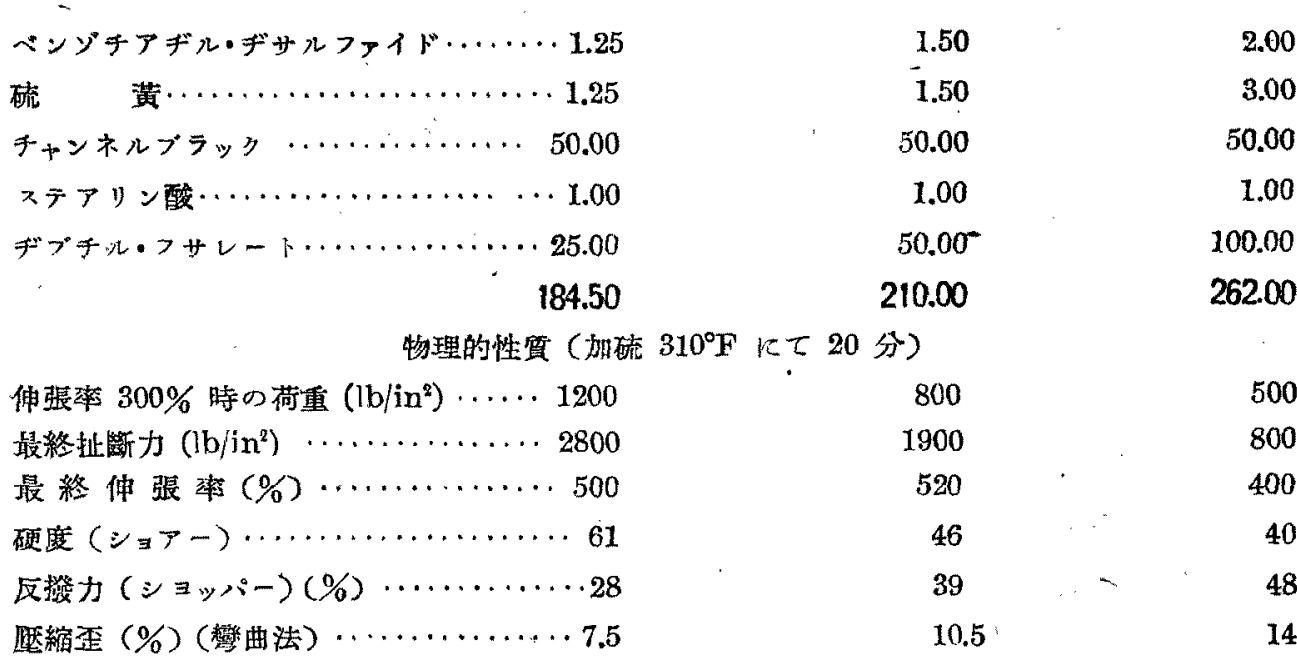

數種の溶劑に浸漬したる時の容積筱化\%

ヘクザン 48 時間 $25^{\circ} \mathrm{C} \cdots \cdots \cdots \cdots+3.0$

*......過剩の可塑架名抽出され收縮す

\section{ブラックの研究}

次に揭ぐる三配合はチャンネルブラック、準補强㗏系ブラック及び軟質系ブラックを混合せる代表的配合物 である。下に示す如き配合にてはチャンネルブラック100 部は混合され得る最大量である。然るに他のブラ。

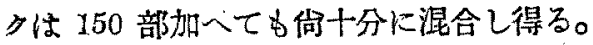

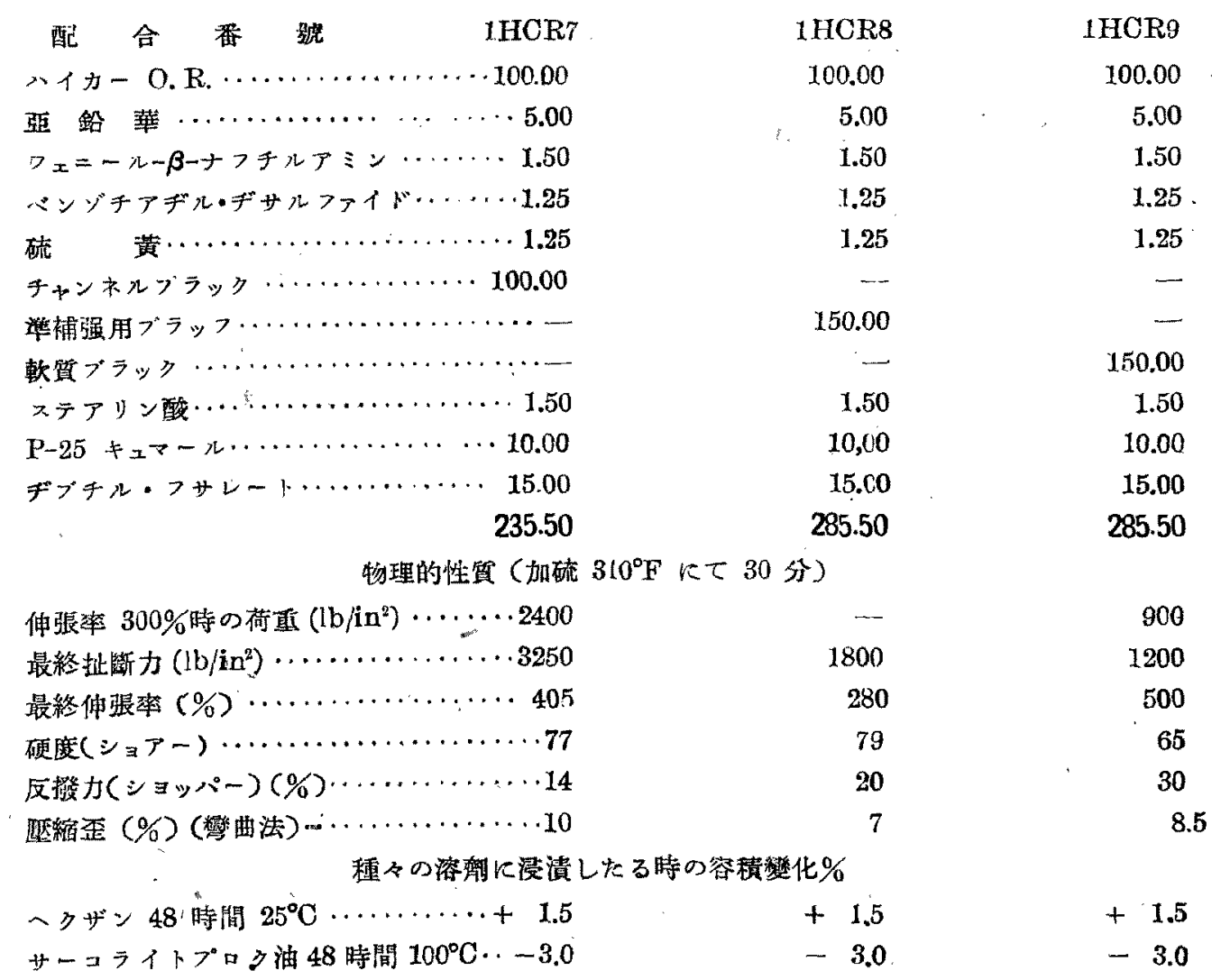

